\title{
Pendidikan Lingkungan dalam Pelajaran Bahasa Indonesia
}

Kerusakan lingkungan hidup merupakan deteorisasi lingkungan yang ditandai dengan hilangnya sumber daya tanah, air, udara, punahnya fauna liar, dan kerusakan ekosistem. Kerusakan lingkungan merupakan salah satu ancaman yang paling berbahaya untuk kelangsungan hidup manusia dan sudah diperingatkan langsung oleh High Level Threat Panel PBB. Saat alam rusak karena dihancurkan dan kehilangan sumber daya, itu merupakan tanda bahwa lingkungan mengalami kerusakan. Lingkungan alam yang rusak sangat berdampak terhadap kehidupan manusia sehingga berpotensi menghasilkan bencana untuk saat ini dan untuk masa-masa yang akan datang. Rusaknya alam bisa disebabkan oleh faktor alam dan juga manusia. Manusia saat ini semakin serakah dan tidak memperhatikan lingkungan. Mereka sama sekali tidak peduli dengan kelangsungan alam untuk masa yang akan datang. Padahal jika kita tidak bisa menjaga lingkungan, tentu saja diri kita sendiri dan anak cucu kita yang akan rugi. Sebaliknya, jika kita menjaganya pasti generasi mendatang masih bisa menikmati keindahan alam dan memanfaatkannya untuk memenuhi kebutuhan mereka.

Lai (dalam Ramadhan et al, 2019) mengatakan masalah lingkungan secara inheren tidak dapat dipisahkan dari kesadaran lingkungan, nilai-nilai, dan sikap orang. Ini mendorong negara untuk mulai menilai pendidikan lingkungan. Pendidikan lingkungan hidup adalah suatu proses untuk membangun populasi manusia di dunia yang sadar dan peduli terhadap lingkungan total (keseluruhan) dan segala masalah yang berkaitan dengannya, dan masyarakat yang memiliki pengetahuan, keterampilan, sikap dan tingkah laku, motivasi serta komitmen untuk bekerja sama, baik secara individu maupun secara kolektif, untuk dapat memecahkan berbagai masalah lingkungan saat ini, dan mencegah timbulnya masalah baru (UNESCO, Deklarasi Tbilisi, 1977).

Menurut Buldur dan Lai (dalam Ramadhan et al, 2019) pendidikan lingkungan dapat membantu siswa memikirkan kembali korelasi antara manusia dan lingkungan, mulai memahami lingkungan mereka, menyadari masalah lingkungan dan mempertimbangkan masalah lingkungan yang berkaitan dengan kehidupan mereka. Sebagai subjek kegiatan pedagogis, guru harus menghasilkan pengetahuan, kepercayaan, dan keterampilan dalam pelestarian lingkungan dan perlindungan alam. Untuk mencapai hal ini, guru harus memiliki minat dalam menggunakan tema yang terkait dengan masalah global mengenai lingkungan, memiliki pemahaman yang berkualitas, dan sikap positif terhadap lingkungan. Guru bahasa berada dalam posisi unik untuk mempromosikan kesadaran lingkungan. Dengan mengintegrasikan pendidikan lingkungan ke dalam kelas bahasa, para pendidik dapat meningkatkan minat siswa dalam masalah kontemporer yang mungkin secara langsung mempengaruhi masa depan mereka; mengajar siswa bagaimana berkontribusi pada dunia yang lebih sehat dan berkelanjutan; dan mempromosikan pembelajaran dan komunikasi bahasa yang bermakna.

Dari hasil penelitian penulis $72,9 \%$ sangat setuju, $27,1 \%$ setuju bila topik tentang kebersihan sangat perlu dalam materi pembelajaran bahasa Indonesia. 57,6\% sangat setuju, 
$42,4 \%$ setuju bila teks tentang lingkungan sangat tepat digunakan dalam materi pembelajaran bahasa Indonesia. 50,8\% sangat setuju, 49,2\% setuju jika jenis teks persuasif tentang kebersihan sangat tepat digunakan dalam materi pelajaran bahasa Indonesia. 54,2\% sangat setuju, 39\% setuju, dan 6,8 kurang setuju jika guru dalam memberikan pelajaran bahasa Indonesia memilih teks yang ada kaitannya dengan lingkungan sekitar. 61\% sangat setuju, 39\% setuju bila materi tentang pemanfaatan barang bekas sangat efektif untuk mengajak siswa menjaga lingkungan. $83,1 \%$ sangat setuju, $16,9 \%$ setuju bila guru harus memberikan contoh bagaimana menjaga kebersihan lingkungan. $61 \%$ sangat setuju, 39\% setuju dengan adanya teks tentang mengurangi pemakaian plastik siswa diharapkan dapat menerapkannya. 45,8\% sangat setuju, 54,2\% setuju bila teks tentang lingkungan dapat mempengaruhi pola hidup siswa. 47,5\% sangat setuju, 45,8\% setuju, dan 6,7\% kurang setuju jika membuat cerita tentang lingkungan membuat siswa lebih peduli tentang lingkungannya. 52,5\% sangat setuju 40,7\% setuju, dan 6,8\% kurang setuju jika guru membuat teks yang menarik tentang lingkungan untuk membuat siswa tertarik terhadap lingkungan.

Dari hasil penelitian penulis diketahuhi bahwa guru bahasa memainkan peran penting dalam mengintegrasikan pendidikan lingkungan dalam pembelajaran bahasa. Guru dapat menggunakan masalah global sebagai konteks untuk mengembangkan keterampilan bahasa. Konteks ini dapat diintegrasikan ke dalam teks yang sedang dipelajari. Sesuai dengan kurikulum pembelajaran bahasa, yaitu pembelajaran bahasa berbasis teks. Melalui teks yang dipelajari, siswa memperoleh pengetahuan tentang lingkungan dan diharapkan memiliki dampak pada perilaku sadar lingkungan. Pendidikan lingkungan dapat dilihat melalui desain pembelajaran yang digunakan oleh guru. 


\section{Daftar Rujukan}

Buldur A and Ömeroglu E 2018 An examination of the relationship between pre-school children's and their teacher' attitute and awareness towards the environment Journal of Education and Learning 7(2) 221-9

Fidan N and Ay T S 2016 Acquisition of operational environmental literacy in social studies course International Journal of Environmental \& Science Education 11(13) 5951-68

Gürsoy E and Sağlam G T 2011 ELT teacher trainers' attitute towards environmental education and their tendency to use in the language classroom Journal of International Education Research 7(4) 47-52

Hauchild S, Poltavthenko E and Stoller F L 2012 Going green: Menging environmental education and language instruction English Teaching Forum Number 2 2-13

Lai C S 2018 A study of fifth graders' environmental learning outcomes in Taipei International Journal of Research in Education and Science 4(1) 252-61

Loubser C P, Swanepoel C H and Chacko C P C 2001 Concept formulation for environmental literacy South Africal Journal of Education 21(4) 317-323

Nazarenko A V and Kolesnik A I 2018 Raising environmental awareness of future teachers International Journal of Instruction 11(3) 63-76

Ramadhan, S., Sukma, E., \& Indriyani, V. (2019). Environmental education and disaster mitigation through language learning. IOP Conference Series: Earth and Environmental Science, 314. 